\title{
Logistics competitiveness of OECD countries using an improved TODIM method
}

\author{
MIHRIMAH OZMEN \\ Department of Industrial Engineering, Erciyes University, Kayseri, Turkey \\ e-mail: mihrimah@erciyes.edu.tr
}

MS received 11 July 2018; revised 31 December 2018; accepted 5 January 2019; published online 6 April 2019

\begin{abstract}
The Organization for Economic Co-operation and Development (OECD) provides a forum where governments can work together to increase the global welfare and to seek solutions to common problems through economic growth, where logistics plays an important role and contributes to financial stability. Evaluation of the logistics competitiveness of countries is a technical decision-making issue involving a variety of criteria. Most importantly, these criteria usually conflict with each other and they often act and react upon one another. As in logistics competitiveness as well as in many decision-making problems, the relationships among criteria are interdependent. Moreover, different dimensions and criteria weights also affect the evaluation results. By considering these situations, in order to handle these criteria interactions, Mahalanobis distance (MD) based TODIM (an acronym in Portuguese for Interactive and Multicriteria Decision Making) method has been developed and it has been applied to evaluate the logistics competitiveness of the OECD countries. Evaluation of the correlation between criteria develops the consideration outcomes (regarding sorting) to a certain degree with the traditional TODIM method.
\end{abstract}

Keywords. Logistics competitiveness; OECD countries; Mahalanobis distance; TODIM; criteria dependency.

\section{Introduction}

International trade has recently been influenced by globalization and the increasing competitiveness of overdue territories that have not played an important role in the world in the past years. This tendency has had an excessive effect on logistics, as it is one of the base items that facilitates the mobility of products, ensures security and speed, and reduces costs when international trade increases between countries [1]. Logistics has been defined as, "the process of strategically managing the movement and storage of materials, parts and finished inventory from suppliers, through the firm and on to the customers" [2].

The logistics can be understood through its principles [3]. The principle of coordination ensures the flow of accurate information between planners, practitioners and end customers to fulfill logistics operations. The principle of simplicity means logistics operations have a simple and easily applicable systematic structure. Logistics operations can be quickly adapted to changing circumstances and varying demands which can be explained by the principle of flexibility. The effective and efficient use of resources in the realization of these operations is explained by the principle of economics. In accordance with conformity to standards principle, in international logistics operations, the standards of materials, services and methodologies used are considered accordingly. The right prioritization of processes principle is the planning of activities such that logistics practices are compatible with other basic principles. The final principle traceability is immediate access to desired information about all logistics workflow and avoiding possible problems that may be encountered at this point.

Supporting logistics is the basis for promoting economic development. For this reason, the OECD countries attach great importance to developing strategies for comprehensive national logistics. At the same time, effective domestic and international logistics is a prerequisite for competing in international trade activities. The logistics competitiveness evaluation is an important problem in order to be able to assess policy impacts and to compare the global developments in logistics. The World Bank Logistics Performance Index (LPI) is used to evaluate the countries. However, logistics competitiveness evaluation, involves multiple criteria and is needed a realistic evaluation like multi criteria decision making (MCDM) technique. To meet this need, the study has proposed a logistics competitiveness evaluation approach in terms of two innovative perspectives. In this study, a new MCDM method of improved TODIM is proposed which considers criteria dependency and using this method the OECD countries are evaluated with new criteria. There are a few MCMD studies on the 
OECD countries which are very rooted and thus affect the world at large, increases the importance of this study.

The TODIM method is an important simple decisionmaking tool, however it can be very comprehensive when it is applied to the evaluation of a decision-making problem [4]. Furthermore, the traditional TODIM method, which is based on nonlinear prospect theory due to the shape of its value function, is the same as the gains/losses function of prospect theory. Hence traditional TODIM do not take criteria dependency and interaction. To address these shortcomings, we proposed improved TODIM method. Unlike the method which combining TODIM and Choquet integral [4], our proposed simple and, easy-to-apply method uses the MD which allows for taking dependencies between criteria into consideration. The MD calculates the relative dominance of each alternative over other alternatives and makes use of the sample covariance matrix and can solve the problem of the relevance among criteria as appropriate.

The paper is structured as follows: Section 2 provides the literature review of the existing studies in this field. Section 3 introduces the improved TODIM method and it is followed by a case study of this method which presents the evaluation of the logistics competitiveness of the OECD countries. Results and discussions are presented in section 5. Lastly, findings of the study have been summarized and some suggestions have been provided for future studies.

\section{Literature review}

\subsection{MCDM applications about OECD countries}

The OECD, whose foundations extend to the Second World War, was established on September 30, 1961, when the contract between the OECD countries was officially entered into force. Today, 35 OECD members from around the world come to define, discuss and to analyze national problems and to solve them. In literature, there are few and insufficient MCDM studies about OECD countries. Wanke et al [5], Zaman et al [6], Kazan et al [7] have employed TOPSIS method to evaluate OECD countries. Rashidi et al [8], Mavi et al [9], Zhou et al [10], Kou et al [11] and Marti et al [1] have applied Data Envelopment Analysis (DEA) models to the OECD countries.

Wanke et al [5] presents a performance assessment of 128 banks from 23 OECD countries from 2004 to 2013, using different financial criteria that emulate the CAMELS (capital adequacy, asset quality, management efficiency, earnings, liquidity and sensitivity to market risk) rating system. A robust TOPSIS approach for assessing bank efficiency has also been developed and presented. Zaman et al [6] has compared the performance of the different climate adaptation strategies using TOPSIS. In the study by Rashidi et al [8], the eco-efficiency of OECD countries is evaluated with energy inputs, undesirable outputs, and nondiscretionary factors. Mavi et al [9] proposed a model to find the common weights with DEA and analyzed the eco-efficiency and eco-innovation of OECD countries. Zhou et al [10] evaluated environmental performance of OECD countries using the proposed non-radial DEA model. Kou et al [11] have proposed a DEA model to measure and decompose the overall efficiency of OECD countries in the multi-period and multi-division context.

\subsection{Logistics competitiveness evaluation}

The importance of efficient logistics for trade growth is widely accepted. The literature has shown that logistics competitiveness is strongly related to trade expansion, export diversification, direct foreign investment and economic growth. The description of competitiveness is difficult for researchers, because organizations have many and often overlapping targets [12-17]. Some of these may include: Quality [13], Vendor performance [14], Productivity [15], Efficiency [16], Competitive position [18], Operating performance [19], Distribution effectiveness [20, 21], Raw financial statistics (e.g., net income, gross sales), Cost statistics (e.g., transport cost, standard labor costs), firm evaluation [22], waste management [23], and input/output measures or performance criteria (e.g., number of shipments/vehicle hour) [12], etc.

Many studies have been carried out about logistics competitiveness: Ambrosini and Routhier [24] compared the objectives, methods and results of logistics sector and the study focused on nine industrialized countries of Europe, America and Asia. Gergin and Baki [25] ranked the logistics competitiveness of the Turkey's regions employing Analytic Hierarchy Process (AHP) and TOPSIS methods. Yang and Chen [26] compared and explored three major international hub ports in Northeast Asia according to logistics competitiveness by using AHP and Grey Relational Analysis (GRA). Ozceylan et al [27] considered logistics competitiveness evaluation of Turkey's provinces. They used geographic information system and MCDM tools to determine logistics scores of 16 geographic and economic indicators. Roy et al [28] applied data mining approaches to LPI dataset and thus extended insights on logistics competitiveness.

However, to the best of our knowledge, there are very limited studies in the literature about logistics competitiveness of OECD countries. Guner and Coskun [17] investigated the relationship between LPI scores and social, economic indicators of the logistics competitiveness of the OECD countries by using a regression analysis. $\mathrm{Yu}$ and Hsiao [29] considered the LPI scores of the differences among technology groups by classifying and comparing the countries as high-income OECD, high-income non-OECD, upper-middle-income, lower-middle-income, and low-income countries by applying the DEA model. Cakir [30] introduced a method to obtain an analysis framework to 
measure logistics competitiveness of OECD countries. The presented method by Çakir consists of criteria importance through inter-criteria correlation (CRITIC), simple additive weighting and Peters' fuzzy regression methods.

Although logistics competitiveness of countries is compared in the aforementioned studies, considering the criteria dependency of logistics competitiveness seems to be very narrow. Jiang and Chen [31] proposed a new evaluation index system for Urban Logistics Capability (ULC) by classification. Hierarchical Cluster Analysis (HCA) and Principal Component Analysis (PCA) methods are applied to classify into 3 clusters for 30 sample cities. PCA transforms the original set of variables into a smaller set. Cakir [30] obtained criteria weights with CRITIC method by considering the criteria interactions to measure logistics competitiveness. Our proposed TODIM improved method provides order of preference and can overcome criteria dependency without eliminating the criteria.

\section{The proposed method: improved TODIM}

\subsection{The traditional TODIM method}

The TODIM (an acronym in Portuguese of interactive and multi-criteria decision making) method, was introduced as a valuable tool for solving the MCDM problem by Gomes and Lima [32]. It depends on gain/loss function of the Prospect Theory [33]. This function can aggregate gains and losses of each alternative over the others with regards to all criteria. TODIM calculates the global value which measures the dominance of each alternative over every other alternative and thereby the ranking of alternatives can be obtained [34].

One of the advantages of TODIM method is that it can be used for qualitative as well as for quantitative criteria. The other one is that it can also capture the decision makers' behavior [34]. Therefore, it has been widely used to deal with MCDM problems in various fields, such as the evaluation of the residential properties available [34], selection of the best location of the natural gas reserves [35], oil spill response [36], ranking chemical industries and thermal power station units [37], and so on.

Suppose there are $m$ alternatives and $n$ quantitative or qualitative criteria and let us assume that one of these criteria is reference criterion. Once these elements are identified, the decision makers are asked to estimate the contribution of each criterion $c$ to each alternative $i$. In mathematical formulation of the TODIM method, the following steps are explained with the parameters below $[32,38]$.

Let $M=\{1,2, \ldots, m\}$ and $N=\{1,2, \ldots, n\}$. Let $A=$ $\left\{A_{1}, A_{2}, \ldots, A_{m}\right\}$ be a finite alternative set, where $A_{i}$ denotes the $i$ th alternative; $C=\left\{C_{1}, C_{2}, \ldots, C_{n}\right\}$ be a finite attribute set, where $C_{j}$ denotes the $j$ th attribute, where $i \in M, j \in N$.
Let $w=\left(w_{1}, w_{2}, \ldots, w_{n}\right)^{T}$ be an attribute weight vector, where $w_{j}$ denotes the weight or the importance degree of attribute $C_{j}$, such that $\sum_{j=1}^{n} w_{j}=1$ and $0 \leq w_{j} \leq 1, j \in N$. $x_{i j}$ is the value of alternative $A_{i}$ with respect to criterion $C_{j}$.

Step 1: Calculate the normalize matrix

$G=\left(g_{i j}\right)_{m \times n}$ of the decision matrix $X=\left(x_{i j}\right)_{m \times n}$.

Step 2: Calculate the trade-off rate $w_{j r}$ of the criterion $C_{j}$ to the reference criterion $C_{r}$ where $w_{j}$ is the weight of the criterion $C_{j}$ and $w_{r}$ is the weight of the reference criterion $w_{r}=\max \left\{w_{j} \mid j \in N\right\}$.

$$
w_{j r}=\frac{w_{j}}{w_{r}}, r, j \in
$$

Step 3: Calculate the dominance of each alternative $P_{i}$ over each alternative $P_{k}$ :

$$
\delta\left(P_{i}, P_{k}\right)=\sum_{j=1}^{n} \emptyset_{j}\left(P_{i}, P_{k}\right), \forall(i, k)
$$

where parameter $\theta$ represents attenuation factor of the losses and $\emptyset_{j}\left(P_{i}, P_{k}\right)$ is the contribution of criterion $C_{j}$ to function $\delta\left(P_{i}, P_{k}\right)$, when comparing alternatives $P_{i}$ with $P_{k}$

$$
\begin{aligned}
& \emptyset_{j}\left(P_{i}, P_{k}\right)= \\
& \begin{cases}\sqrt{\frac{w_{j r}\left(g_{i j}-g_{k j}\right)}{\sum_{l=1}^{n} w_{l r}},} & \text { if } g_{i j}-g_{k j}>0 \\
0, & \text { if } g_{i j}-g_{k j}=0 \\
-\frac{1}{\theta} \sqrt{\frac{\left(\sum_{l=1}^{n} w_{l r}\right)\left(g_{k j}-g_{i j}\right)}{w_{j r}},} & \text { if } g_{i j}-g_{k j}<0\end{cases}
\end{aligned}
$$

Step 4: Calculate the normalized global performance of alternative $P_{i}$, according to all other alternatives

$$
\begin{aligned}
& \xi_{i}=\frac{\sum_{k=1}^{m} \delta\left(P_{i}, P_{k}\right)-\min _{i}\left\{\sum_{k=1}^{m} \delta\left(P_{i}, P_{k}\right)\right\}}{\max _{i}\left\{\sum_{k=1}^{m} \delta\left(P_{i}, P_{k}\right)\right\}-\min _{i}\left\{\sum_{k=1}^{m} \delta\left(P_{i}, P_{k}\right)\right\}}, \\
& i \in M
\end{aligned}
$$

Step 5: Sort the alternatives by their normalized global performance values $\xi_{i},(i \in M)$.

\subsection{The improved TODIM method using the Mahalanobis distance}

Mahalanobis [39] presented the MD as a statistical distance. This distance reflects the covariance distance between variables and gauges the similarity of an unknown sample set to a known one. Thus, the MD is calculated based on the inverse of the variance-covariance matrix of the data set of interest [40]. 
For a multivariate vector $x=\left(x_{1}, x_{2}, \ldots, x_{n}\right)^{T}$, mean vector $\mu=\left(\mu_{1}, \mu_{2}, \ldots, \mu_{p}\right)^{T}$, and covariance matrix $\sum$, the MD is defined as:

$$
D_{M}(x)=\sqrt{(x-\mu)^{T} \sum^{-1}(x-\mu)}
$$

The MD as dissimilarity measure between two random vectors $\vec{x}$ and $\vec{y}$ from the same distribution is defined in Eq. (6):

$$
d(\vec{x}, \vec{y})=\sqrt{(\vec{x}-\vec{y})^{T} \sum^{-1}(\vec{x}-\vec{y})}
$$

MD is basically a weighted distance which is variance and the correlation degree with other criteria. The MD standardizes data via the factor $\sum^{-1}$. Thus, MD processes both the correlation between the data and the effect of the index being of different size. In literature, Wang and Wang [40], developed the TOPSIS method to take into account the dependency between the criteria by taking advantage of the MD. They used weighted MD to improve the TOPSIS method and obtained consistent results.

The TODIM method compares decision criteria pairs. To remove the inconsistencies, these comparisons and to handle the correlations among the criteria, this paper proposes a TODIM modification that obstructs the conflicting information by using the MD.

From the original formulation of TODIM, computation of the term $\emptyset_{j}\left(P_{i}, P_{k}\right)$ is the contribution of criterion $C_{j}$ to function $\delta\left(P_{i}, P_{k}\right)$, when comparing alternatives $P_{i}$ with $P_{k}$ as Eq. (3). Through considering MD from $P_{i}$ to $P_{k}$ and the factor $\sum^{-1}$ of interactions between criteria we can obtain the overall value of each alternative.

This is accomplished by rewritten Eq. (3) as Eq. (7):

$$
\begin{aligned}
& \emptyset_{j}\left(P_{i}, P_{k}\right) \\
& = \begin{cases}\sqrt{\left(g_{i j}-g_{k j}\right)^{T} \Omega_{1}^{T} \sum^{-1} \Omega_{1}\left(g_{i j}-g_{k j}\right),} & \text { if } g_{i j}-g_{k j}>0 \\
0, & \text { if } g_{i j}-g_{k j}=0 \\
-\frac{1}{\theta} \sqrt{\left(g_{k j}-g_{i j}\right)^{T} \Omega_{2}^{T} \sum^{-1} \Omega_{2}\left(g_{k j}-g_{i j}\right),} & \text { if } g_{i j}-g_{k j}<0\end{cases}
\end{aligned}
$$

The expressions $\Omega_{1}$ and $\Omega_{2}$ used in equation (7) are given in Eqs. (8) and (9), respectively. In these expressions the diag symbol means only the components along the diagonal.

$$
\begin{aligned}
& \Omega_{1}=\operatorname{diag}\left(\frac{w_{1 r}}{\sum_{l=1}^{n} w_{1 r}}, \frac{w_{2 r}}{\sum_{l=1}^{n} w_{2 r}}, \ldots, \frac{w_{n r}}{\sum_{l=1}^{n} w_{n r}}\right) \\
& \Omega_{2}=\operatorname{diag}\left(\frac{\sum_{l=1}^{n} w_{1 r}}{w_{1 r}}, \frac{\sum_{l=1}^{n} w_{2 r}}{w_{2 r}}, \ldots, \frac{\sum_{l=1}^{n} w_{n r}}{w_{n r}}\right)
\end{aligned}
$$

\section{Evaluation of the logistics competitiveness of the OECD countries' using the improved TODIM}

The strength of the logistics systems has an important effect on the cost of enterprises [41]. For instance, effectively managed ports and more appropriate hinterland links could lower the costs of establishing logistics networks or of transporting raw materials. Besides, the effectivity of the logistics systems is closely associated with industry profitability. Supplying of the unbalanced demand, delivery in a short time and minimizing the transporting costs are key elements of the company's competitiveness. Having all these in mind, logistics systems are accepted both as a factor of production and as one of the important factors in investment decisions [42].

According to the literature, the foreign direct investments prefer countries according to their logistics competitiveness [43]. Nowadays, the logistics competitiveness of countries is evaluated by LPI scores. It analyzes not only an extensive evaluation of worldwide logistics competitiveness, but also provides performance trends that are comprehensible over time. However, it is necessary to look behind the LPI scores and rankings to assess the country's logistics competitiveness. In this study, a more detailed perspective, which is more beneficial for investors and trade companies, is presented to evaluate the logistics competitiveness of countries with new criteria and the proposed improved TODIM.

In the case study, the 25 OECD countries are identified from different geographical areas and regions in terms of representing the general criteria and the accessibility of data. These countries are evaluated according to 9 criteria. All of these criteria have a critical impact on sectoral competitiveness, but they are also interdependent criteria.

In this section, first the criteria, used in the ranking, is introduced. Then the correlations of the criteria are calculated and evaluated with Pearson analysis. Finally, the rankings of the OECD countries are obtained according to their logistics competitiveness with the improved TODIM method.

\subsection{The dataset and criteria for logistics competitiveness}

Globalization has significantly increased competition in international trade. In this case, logistics is at the forefront and countries have started to be evaluated according to their activities in the field of logistics. In order to be able to make an effective logistics performance assessment, there is a need for comprehensive performance approach at international level. In this context, the World Banks offer a comprehensive international benchmark: LPI, for evaluating countries in terms of logistics [44]. The LPI is used in conjunction with other in-house resources, can initiate discussions on logistics performance and factors driving 
obstacles to performance barriers [42]. However, there is also a need beyond the LPI, which is a comprehensive multidimensional evaluation of trade and transportation performance related to action plans and policies are required.

Many criteria have been used in the applications found in the literature. Cakir, Marti et al, Yu and Hsiao, Guner and Coskun [1, 17, 29, 30] have benefitted from the LPI indicators in their evaluations. Guner and Coskun [17] applied social indicators, in addition to LPI indicators. Jiang and Chen [31] have evaluated the urban logistics capability according to the 10 factors. The factors are grouped as: supply and demand capability, economic development capability and transportation development level. Ozceylan et al [27] proposed that the logistic performance of a province can be addressed within three main dimensions: freight transaction factors, transportation capability factors, and economic and infrastructure factors.

In this study, by considering literature and taking the opinions of academicians and experts in the field of logistics, the dimensions affecting the competitiveness of logistics is constructed. To evaluate the logistics competitiveness of the OECD countries, a total of 9 sub-criteria from two aspects is considered. The aspects are "performance areas" and "transport volumes". The hierarchical structure of criteria is shown in figure 1 and the definitions of the criteria have been given in table 1 . The dataset has been taken from the World Bank and OECD 2016 statistics [44-47].

The "performance areas" aspect is consisting of 6 subcriteria: customs, infrastructure, international shipments, logistics quality, tracking and tracing, and timeliness. These are LPI score components and they are assessed using a 5-point scale. When LPI is calculated, the average of these
6 sub-criteria is taken. Rather than taking the average, we evaluate them separately. Thus, these criteria differing in weight have been evaluated in a more meaningful way.

To the best of our knowledge, there are similar approaches in the literature, but in the logistics competitiveness comparison, "transportation volumes" aspect is used for the first time in this study. The sub-criteria of "transportation volumes": the freight, container and passenger transportation volumes have been considered. These criteria can be applied to identify the challenges and opportunities related to the transport infrastructure, logistics competence and supply chain effectiveness of the trading country. In this context, they can be useful criteria for trade logistics competitiveness of countries, and at the same time this can be considered as a reference in selecting locations for logistics operations [42]. Besides, considering the contradiction between transport volume and logistics performance allows to have a more realistic perspective.

The decision matrix of OECD countries with 9 sub-criteria values and their weights are given in table 2 . In order to determine the criteria weights for evaluating the countries considering logistics; opinion of the decision makers (i.e., experts in logistics, academicians and logistics firms) were taken. The weights of the criteria are based on most of the research using AHP [48]. Table 2 shows a list of criteria, with their assigned weights. The total sub-criteria weights were calculated by multiplying their own "subcriteria weight" and "main criteria weight". Besides, the other rows of table 2 , there are the criteria values of the countries.

When the main criteria weights which affecting evaluation of the countries, are examined, we observe that "A. The performance areas" with \%65 weight, is more important than "B. The transportation volumes" has \%35 weight.

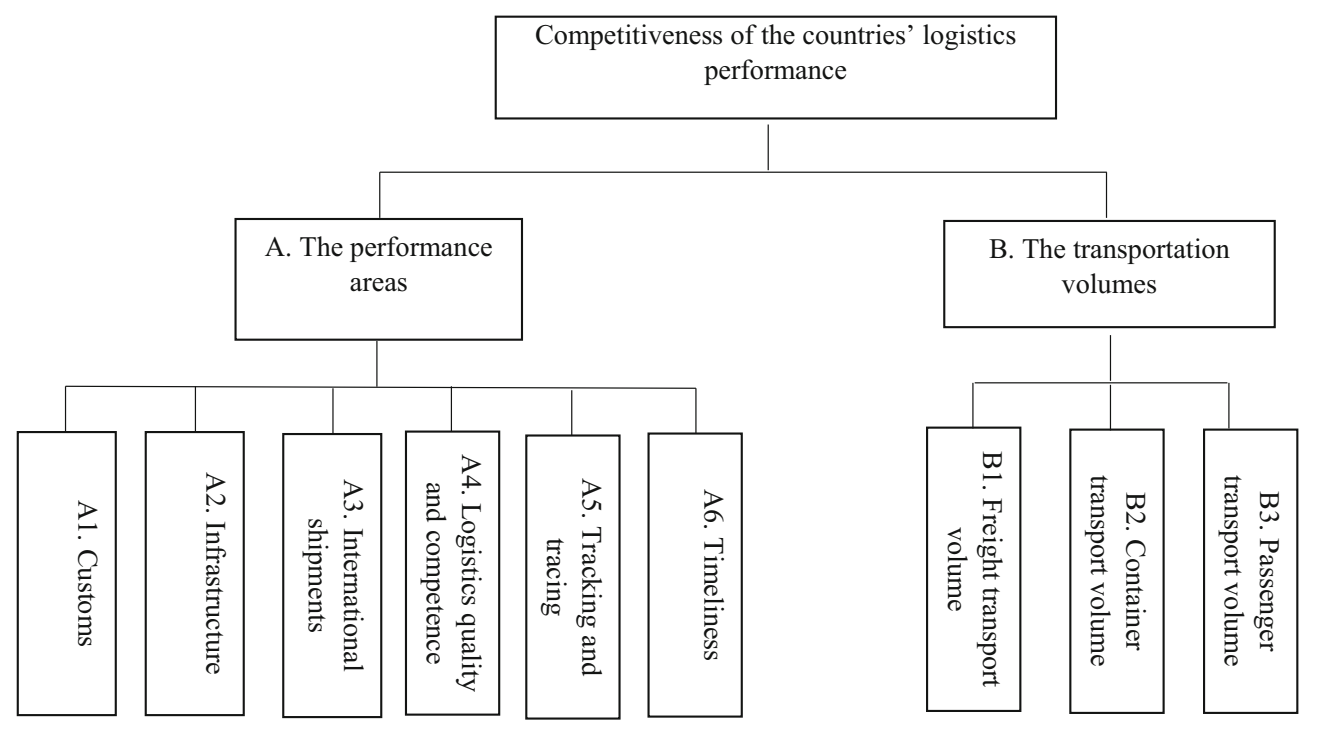

Figure 1. The hierarchical structure of logistics competitiveness of countries. 
Table 1. The definitions of the criteria [44-47].

\begin{tabular}{|c|c|c|c|}
\hline $\begin{array}{l}\text { Main } \\
\text { Criteria }\end{array}$ & & Sub-Criteria & Definition \\
\hline \multirow{6}{*}{$\begin{array}{l}\text { A. The } \\
\text { performance } \\
\text { areas }\end{array}$} & A1 & Customs & $\begin{array}{c}\text { "Efficiency of the clearance process (i.e., speed, simplicity and predictability of } \\
\text { formalities) by border control agencies, including customs" }\end{array}$ \\
\hline & A2 & Infrastructure & $\begin{array}{c}\text { "Quality of trade and transport related infrastructure (e.g., ports, railroads, roads, } \\
\text { information technology)" }\end{array}$ \\
\hline & $\mathbf{A 3}$ & $\begin{array}{r}\text { International } \\
\text { shipments }\end{array}$ & "Ease of arranging competitively priced shipments" \\
\hline & A4 & $\begin{array}{l}\text { Logistics quality and } \\
\text { competence }\end{array}$ & $\begin{array}{c}\text { "Competence and quality of logistics services (e.g., transport operators, customs } \\
\text { brokers)" }\end{array}$ \\
\hline & A5 & Tracking and tracing & "Ability to track and trace consignments" \\
\hline & A6 & Timeliness & $\begin{array}{c}\text { "Timeliness of shipments in reaching destination within the scheduled or expected } \\
\text { delivery time" }\end{array}$ \\
\hline \multirow[t]{3}{*}{$\begin{array}{l}\text { B. The } \\
\text { transportation } \\
\text { volumes }\end{array}$} & B1 & $\begin{array}{l}\text { Freight } \\
\text { transportation } \\
\text { volume }\end{array}$ & $\begin{array}{l}\text { "It refers to the total movement of goods using inland transport on a given network. } \\
\text { Data are expressed in million tonne-kilometres, which represents the transport of } \\
\text { one tonne over one kilometre. Components for road and rail are available" }\end{array}$ \\
\hline & B2 & $\begin{array}{l}\text { Container } \\
\text { transportation } \\
\text { volume }\end{array}$ & $\begin{array}{l}\text { "It refers to the transportation of goods in standardized re-sealable transportation } \\
\text { boxes by rail and sea. Data are expressed in tons and twenty-foot equivalent units } \\
\text { (TEU). TEU is based on a container of } 20 \text {-foot length }(6.10 \mathrm{~m}) \text { providing a } \\
\text { standardized measure of containers of various volumes and for describing the } \\
\text { capacity of container ships or terminals. One } 20 \text { foot container equals } 1 \text { TEU" }\end{array}$ \\
\hline & B3 & $\begin{array}{l}\text { Passenger } \\
\text { transportation } \\
\text { volume }\end{array}$ & $\begin{array}{c}\text { "It refers to the total movement of passengers using inland transport on a given } \\
\text { network. Data are expressed in million passenger-kilometers, which represents the } \\
\text { transport of a passenger for one kilometer. Components for road and rail are } \\
\text { available" }\end{array}$ \\
\hline
\end{tabular}

The most important sub-criterion is "A4. Logistics quality and competence" has \%18.2 weight. This value is obtained by multiplying the following two values: the weight of "The performance areas" (\%65) and the weight of "Logistics quality and competence" (\%28) between the performance areas sub-criteria.

\subsection{Data correlation testing}

To validate the newly proposed improved TODIM and to examine the relation between the criteria, the correlation of the 9 sub-criteria with evaluation index was conducted using Pearson analysis. The results given in table 3 shows that most of the sub-criteria especially the performance areas' sub-criteria are significantly correlated to one another at a confidence level of more than 95\%. Especially, all performance areas sub-criteria (A1. Customs, A2. Infrastructure, A3. International shipments, A4. Logistics quality and competence, A5. Tracking and tracing, A6. Timeliness) and all transportation volumes sub-criteria (B1. Freight transportation volume, B2. Container transportation volume, B3. Passenger transportation volume) are correlated to each other within themselves. Besides, "B2. Container transportation volume" is correlated to "A2. Infrastructure". This high level of correlations among the criteria has led to doubts about the validity and reliability of the results obtained with the traditional TODIM method.
These 9 logistics competitiveness criteria are highly dependent on each other. This dependency between the criteria affects the validity of the ranks obtained by traditional methods. On the basis of this, TODIM method is applied in order to avoid correlation among the criteria.

\section{Results and discussion}

In accordance with these interdependent criteria, the modified TODIM method was applied to establish the links between these criteria and to evaluate the priority relations in accordance with the structure of the data. The countries were compared with modified TODIM.

First, the contribution of each criterion when comparing the countries were calculated with MD, using Eq. (3). Then, using Eqs. (1)-(4), the dominance of each alternative and overall prospect values was calculated. The obtained ranking results are presented in table 4 . Shading has been used to easily show where other methods have acted in a similar manner. When the results that are obtained by both methods are examined, it is observed that there are significant and reasonable differences in the rank ordering of the two methods. In view of correlation between criteria, to have these differences is an expected situation.

The proposed method can really reflect the characteristics of the logistics competitiveness of the countries, 
Table 2. Decision matrix of OECD countries.

\begin{tabular}{|c|c|c|c|c|c|c|c|c|c|}
\hline \multirow{3}{*}{$\begin{array}{l}\text { Main Criteria } \\
\text { Weight } \\
\text { Sub-Criteria }\end{array}$} & \multicolumn{6}{|c|}{ A. The performance areas } & \multicolumn{3}{|c|}{ B. The transportation volumes } \\
\hline & \multicolumn{6}{|c|}{$65.00 \%$} & \multicolumn{3}{|c|}{$35.00 \%$} \\
\hline & A1 & $\mathrm{A} 2$ & A3 & A4 & A5 & A6 & B1 & B2 & B3 \\
\hline Weight & $10.00 \%$ & $26.00 \%$ & $11.00 \%$ & $28.00 \%$ & $15.00 \%$ & $11.00 \%$ & $44.00 \%$ & $39.00 \%$ & $17.00 \%$ \\
\hline Total Weight & $6.50 \%$ & $16.90 \%$ & $7.15 \%$ & $18.20 \%$ & $9.75 \%$ & $7.15 \%$ & $15.40 \%$ & $13.65 \%$ & $5.95 \%$ \\
\hline OECD Country & \multicolumn{9}{|c|}{ Criteria Values } \\
\hline Austria & 3.79 & 4.08 & 3.85 & 4.18 & 4.36 & 4.37 & 88329 & 1248863 & 12578 \\
\hline Czech Republic & 3.58 & 3.36 & 3.65 & 3.65 & 3.84 & 3.94 & 134075 & 1548782 & 182710 \\
\hline Germany & 4.12 & 4.44 & 3.86 & 4.28 & 4.27 & 4.45 & 936848 & 21126134 & 2246188 \\
\hline Denmark & 3.82 & 3.75 & 3.66 & 4.01 & 3.74 & 3.92 & 33062 & 920621 & 146394 \\
\hline Spain & 3.48 & 3.72 & 3.63 & 3.73 & 3.82 & 4.00 & 264674 & 14995617 & 26670 \\
\hline Estonia & 3.41 & 3.18 & 3.07 & 3.18 & 3.25 & 4.08 & 18112 & 258315 & 6622 \\
\hline Finland & 4.01 & 4.01 & 3.51 & 3.88 & 4.04 & 4.14 & 74885 & 1543866 & 138260 \\
\hline France & 3.71 & 4.01 & 3.64 & 3.82 & 4.02 & 4.25 & 385773 & 4515724 & 1883256 \\
\hline United Kingdom & 3.98 & 4.21 & 3.77 & 4.05 & 4.13 & 4.33 & 196938 & 10230000 & 65012 \\
\hline Greece & 2.85 & 3.32 & 2.97 & 2.91 & 3.59 & 3.85 & 254 & 4206797 & 1192 \\
\hline Hungary & 3.02 & 3.48 & 3.44 & 3.35 & 3.40 & 3.88 & 108893 & 736798 & 163906 \\
\hline Ireland & 3.47 & 3.77 & 3.83 & 3.79 & 3.98 & 3.94 & 23330 & 932705 & 1990 \\
\hline Iceland & 3.13 & 3.02 & 3.32 & 3.26 & 3.42 & 3.88 & 23 & 0 & 14602 \\
\hline Israel & 3.50 & 3.49 & 3.38 & 3.60 & 3.72 & 4.27 & 1404 & 2928228 & 2645 \\
\hline Italy & 3.45 & 3.79 & 3.65 & 3.77 & 3.86 & 4.03 & 72379 & 12067218 & 1717156 \\
\hline Lithuania & 3.42 & 3.57 & 3.49 & 3.49 & 3.68 & 4.14 & 89935 & 509265 & 57222 \\
\hline Latvia & 3.11 & 3.24 & 3.28 & 3.29 & 3.42 & 3.62 & 61707 & 444823 & 5548 \\
\hline Mexico & 2.88 & 2.89 & 3.00 & 3.14 & 3.40 & 3.38 & 671632 & 5682300 & 1039698 \\
\hline Norway & 3.57 & 3.95 & 3.62 & 3.70 & 3.82 & 3.77 & 3312 & 995193 & 3695 \\
\hline Poland & 3.27 & 3.17 & 3.44 & 3.39 & 3.46 & 3.80 & 731456 & 3660279 & 19175 \\
\hline Portugal & 3.37 & 3.09 & 3.24 & 3.15 & 3.65 & 3.95 & 2622 & 3335977 & 4146 \\
\hline Slovak Republic & 3.28 & 3.24 & 3.41 & 3.12 & 3.12 & 3.81 & 91337 & 618227 & 74520 \\
\hline Slovenia & 2.88 & 3.19 & 3.10 & 3.20 & 3.27 & 3.47 & 12990 & 1323240 & 680 \\
\hline Sweden & 3.92 & 4.27 & 4.00 & 4.25 & 4.38 & 4.45 & 127984 & 1546120 & 276172 \\
\hline Turkey & 3.18 & 3.49 & 3.41 & 3.31 & 3.39 & 3.75 & 601775 & 9551735 & 610354 \\
\hline
\end{tabular}

Table 3. The results of correlation test.

\begin{tabular}{|c|c|c|c|c|c|c|c|c|c|}
\hline & $\mathrm{A} 1$ & $\mathrm{~A} 2$ & A 3 & A4 & A5 & A6 & B1 & B2 & B3 \\
\hline A1 & 1 & $0.847 * *$ & $0.803 * *$ & $0.898 * *$ & $0.82 * *$ & $0.82 * *$ & 0.104 & 0.294 & 0.264 \\
\hline $\mathrm{A} 2$ & $0.847 * *$ & 1 & $0.844 * *$ & $0.91 * *$ & $0.876^{* *}$ & $0.763 * *$ & 0.132 & $0.411 * *$ & 0.372 \\
\hline A 3 & $0.803 * *$ & $0.844 * *$ & 1 & $0.915^{* *}$ & $0.817 * *$ & $0.688 * *$ & 0.111 & 0.273 & 0.241 \\
\hline $\mathrm{A} 4$ & $0.898 * *$ & $0.91 * *$ & $0.915^{* *}$ & 1 & $0.9 * *$ & $0.743^{* *}$ & 0.153 & 0.338 & 0.322 \\
\hline A5 & $0.82 * *$ & $0.876^{* *}$ & $0.817 * *$ & $0.9 * *$ & 1 & $0.778 * *$ & 0.088 & 0.328 & 0.302 \\
\hline A6 & $0.82 * *$ & $0.763 * *$ & $0.688 * *$ & $0.743 * *$ & $0.778 * *$ & 1 & 0.008 & 0.274 & 0.235 \\
\hline B1 & 0.104 & 0.132 & 0.111 & 0.153 & 0.088 & 0.008 & 1 & $0.638 * *$ & $0.609 * *$ \\
\hline B2 & 0.294 & $0.411 * *$ & 0.273 & 0.338 & 0.328 & 0.274 & $0.638 * *$ & 1 & $0.649 * *$ \\
\hline B3 & 0.264 & 0.372 & 0.241 & 0.322 & 0.302 & 0.235 & $0.609 * *$ & $0.649 * *$ & 1 \\
\hline
\end{tabular}

**Significantly correlated to one another at a $95 \%$ confidence level.

considering the correlation between the criteria. The normalized global values calculated with the two methods are given in the following line chart. Figure 2 gives that with respect to normalized global value. The traditional TODIM method cannot incorporate the information overlap into the decision-making process. The improved TODIM method attaches to overlapped information and softens the normalized global value. Thus, it can reflect the real conditions between the independent criteria.

The modified method gives more proper implications than the traditional TODIM method for administrative cases. 
Table 4. The comparative results of OECD countries' evaluation obtained from traditional and improved TODIM methods.

\begin{tabular}{|c|c|c|c|c|c|}
\hline & \multicolumn{2}{|c|}{ Traditional TODIM } & \multicolumn{2}{|c|}{ Improved TODIM } & \multirow[b]{2}{*}{ Differ } \\
\hline & $\begin{array}{l}\text { Normalized } \\
\text { global value }\end{array}$ & Order & $\begin{array}{l}\text { Normalized } \\
\text { global value }\end{array}$ & Order & \\
\hline Austria & 0.494 & 8 & 0.827 & 5 & 3 \\
\hline $\begin{array}{l}\text { Czech } \\
\text { Republic }\end{array}$ & 0.453 & 10 & 0.681 & 11 & 1 \\
\hline Germany & 1.000 & 1 & 1.000 & 1 & 0 \\
\hline Denmark & 0.410 & 11 & 0.709 & 9 & 2 \\
\hline Spain & 0.562 & 6 & 0.730 & 8 & 2 \\
\hline Estonia & 0.092 & 21 & 0.317 & 21 & 0 \\
\hline Finland & 0.494 & 9 & 0.770 & 7 & 2 \\
\hline France & 0.755 & 2 & 0.880 & 2 & 0 \\
\hline $\begin{array}{l}\text { United } \\
\text { Kingdom }\end{array}$ & 0.655 & 4 & 0.869 & 4 & 0 \\
\hline Greece & 0.084 & 23 & 0.131 & 23 & 0 \\
\hline Hungary & 0.262 & 18 & 0.401 & 18 & 0 \\
\hline Ireland & 0.335 & 13 & 0.688 & 10 & 3 \\
\hline Iceland & 0.062 & 24 & 0.320 & 20 & 4 \\
\hline Israel & 0.303 & 16 & 0.625 & 12 & 4 \\
\hline Italy & 0.671 & 3 & 0.796 & 6 & 3 \\
\hline Lithuania & 0.325 & 15 & 0.621 & 13 & 2 \\
\hline Latvia & 0.092 & 22 & 0.245 & 22 & 0 \\
\hline Mexico & 0.335 & 14 & 0.020 & 24 & 10 \\
\hline Norway & 0.288 & 17 & 0.619 & 14 & 3 \\
\hline Poland & 0.380 & 12 & 0.469 & 16 & 4 \\
\hline Portugal & 0.190 & 19 & 0.428 & 17 & 2 \\
\hline $\begin{array}{l}\text { Slovak } \\
\quad \text { Republic }\end{array}$ & 0.175 & 20 & 0.330 & 19 & 1 \\
\hline Slovenia & 0.000 & 25 & 0.000 & 25 & 0 \\
\hline Sweden & 0.621 & 5 & 0.872 & 3 & 2 \\
\hline Turkey & 0.503 & 7 & 0.478 & 15 & 8 \\
\hline
\end{tabular}

i. Some of the rankings of certain countries have risen to the top, while others have fallen in rank. There has been no change in the rank ordering of the 8 countries and in the rank ordering of 8 countries, there have been differences 1 or 2 . However, there have been serious differences in the rank ordering of 9 countries. The result that has been obtained with the traditional TODIM method is exaggerated, because the correlation between criteria is ignored. The rank ordering differences can also be explained in a similar manner.

ii. The traditional TODIM method does not consider the dependencies between criteria, which significantly underestimates the logistics competitiveness of Mexico. According to TODIM method, Mexico's rank ordering is 14 . However, by taking out the interaction effect between the criteria, the improved TODIM method calculates the rank ordering as 24 . This great difference is crucial for the decision of countries and /or companies to invest and trade.

iii. The differences between the order obtained by LPI, Traditional TODIM and Improved TODIM are given in table 5. The improved TODIM orders are closer to the LPI orders than the traditional TODIM order. Hence, the rank calculated with the improved TODIM method are more consistent with the globally accepted LPI score rank. The rankings with shading are situations where methods have acted in the same way with LPI during the comparison of country rankings. Thus, the improved TODIM method, which analyzes the criteria correlation, has successful applicability in countries for logistics

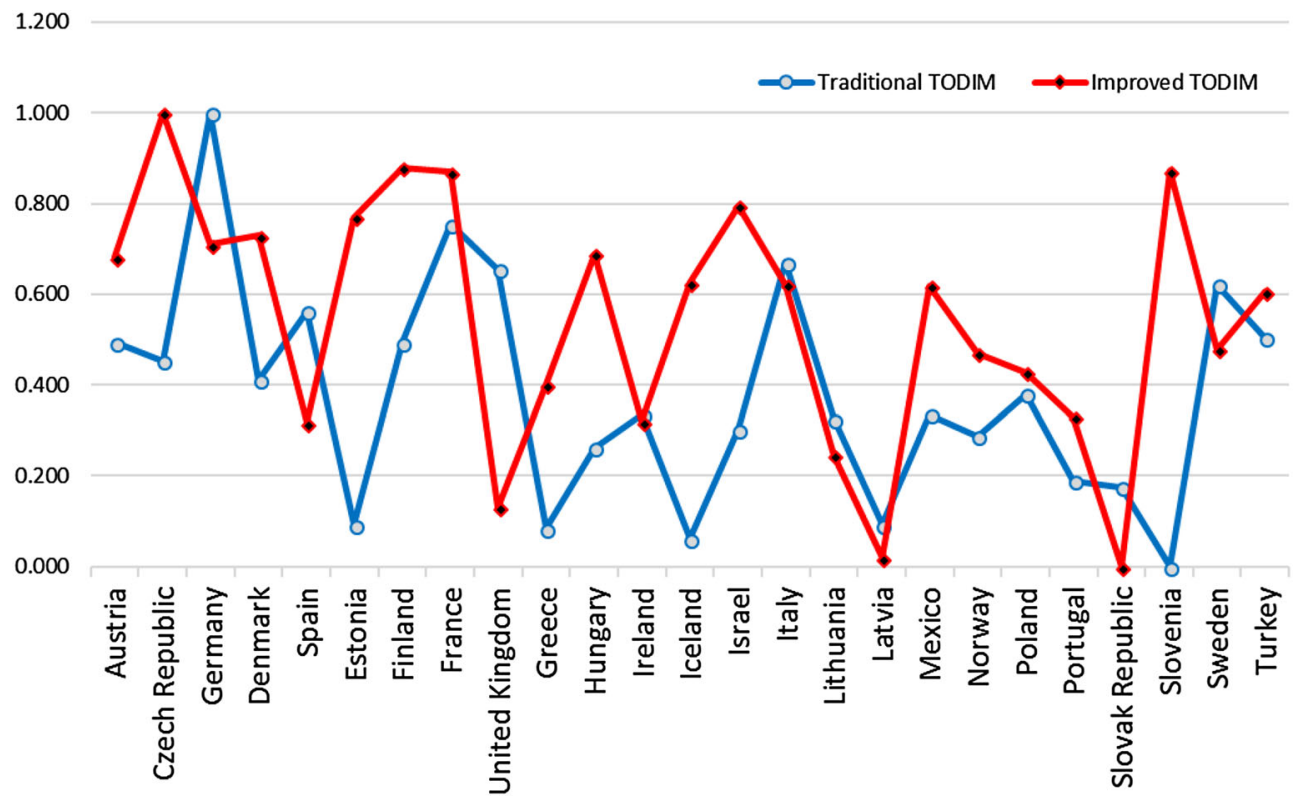

Figure 2. The comparative results of the evaluation of OECD countries obtained from traditional and improved TODIM methods. 
Table 5. The comparison of the LPI, Traditional TODIM and Improved TODIM.

\begin{tabular}{|c|c|c|c|c|c|c|}
\hline & \multicolumn{2}{|c|}{ LPI } & \multicolumn{2}{|c|}{$\begin{array}{c}\text { Traditional } \\
\text { TODIM }\end{array}$} & \multicolumn{2}{|c|}{$\begin{array}{c}\text { Improved } \\
\text { TODIM }\end{array}$} \\
\hline & Score & Order & Order & Differ & Order & Differ \\
\hline Austria & 4.105 & 3 & 8 & 5 & 5 & 2 \\
\hline Czech Republic & 3.67 & 12 & 10 & 2 & 11 & 1 \\
\hline Germany & 4.237 & 1 & 1 & 0 & 1 & 0 \\
\hline Denmark & 3.817 & 7 & 11 & 4 & 9 & 2 \\
\hline Spain & 3.73 & 11 & 6 & 5 & 8 & 3 \\
\hline Estonia & 3.362 & 19 & 21 & 2 & 21 & 2 \\
\hline Finland & 3.932 & 5 & 9 & 4 & 7 & 2 \\
\hline France & 3.909 & 6 & 2 & 4 & 2 & 4 \\
\hline United Kingdom & 4.079 & 4 & 4 & 0 & 4 & 0 \\
\hline Greece & 3.249 & 23 & 23 & 0 & 23 & 0 \\
\hline Hungary & 3.429 & 15 & 18 & 3 & 18 & 3 \\
\hline Ireland & 3.797 & 8 & 13 & 5 & 10 & 2 \\
\hline Iceland & 3.339 & 20 & 24 & 4 & 20 & 0 \\
\hline Israel & 3.66 & 13 & 16 & 3 & 12 & 1 \\
\hline Italy & 3.759 & 9 & 3 & 6 & 6 & 3 \\
\hline Lithuania & 3.632 & 14 & 15 & 1 & 13 & 1 \\
\hline Latvia & 3.327 & 22 & 22 & 0 & 22 & 0 \\
\hline Mexico & 3.115 & 25 & 14 & 11 & 24 & 1 \\
\hline Norway & 3.739 & 10 & 17 & 7 & 14 & 4 \\
\hline Poland & 3.422 & 16 & 12 & 4 & 16 & 0 \\
\hline Portugal & 3.409 & 18 & 19 & 1 & 17 & 1 \\
\hline Slovak Republic & 3.33 & 21 & 20 & 1 & 19 & 2 \\
\hline Slovenia & 3.185 & 24 & 25 & 1 & 25 & 1 \\
\hline Sweden & 4.212 & 2 & 5 & 3 & 3 & 1 \\
\hline Turkey & 3.422 & 16 & 7 & 9 & 15 & 1 \\
\hline
\end{tabular}

performance competitiveness and important scientific assessment and for decision making. The results of improved TODIM are closer to real-life preferences than the traditional TODIM method for applied cases.

\section{Conclusion}

Evaluation of the logistics competitiveness of countries has a potential impact on policy components as well as on projects for the future to improve trade barriers and to identify priority areas regarding limited investment resources. Considering these issues, it would be significant to examine countries more technically like MCDM approach than a score evaluation. In this study, a new approach is modeled to evaluate logistics competitiveness of countries by taking into consideration both logistics performance areas and logistics transportation volumes. Instead of taking the averages (as in the LPI score), by separately evaluating the six logistics performance areas (which has different importance), a more objective perspective was developed. The identified criteria are also quite dependent on each other. Therefore, this case has been solved with a new TODIM method that has improved by using MD that takes account of the inter-criteria relation and the method was performed to evaluate the competitiveness assessment of the logistics of OECD countries.

With this study, the following important contributions have been made to the literature: (1) a multi-dimensional and international logistics competitiveness MCDM tool have been modeled. The model considers two aspects: performance areas and transportation volumes with 9 sub-criteria. (2) to solve this model, a new modified TODIM method has been proposed. The modified TODIM can obtain accurate results with dependent criteria. The numerical results show that the proposed model is effective in evaluating countries' logistics competitiveness even with interactive and interdependent criteria. The improved approach can be implemented with many other logistics decision problems such as: determination of logistics center location, supplier selection, logistics service provider evaluation, route selection of multimodal transportation network, etc. In addition, the application of improved TODIM in the stochastic $[49,50]$ and fuzzy environment, integration and comparison with other methods can be considered as a topic for future research.

\section{References}

[1] Martí L, Martín J C and Puertas R 2017 A DEA-LOGISTICS PERFORMANCE INDEX. Journal of Applied Economics 20(1): 169-192

[2] Erkayman B, Gundogar E and Akkaya G and Ipek M 2011 A fuzzy TOPSIS approach for logistics center location selection. Journal of Business Case Studies 73: 49

[3] Koban E and Keser H Y 2008 D1ş ticarette lojistik. Ekin Basım Yayın Dă̆ıtım

[4] Gomes L F A M, Machado M A S, da Costa F F and Rangel L A 2013 Criteria interactions in multiple criteria decision aiding: A Choquet formulation for the TODIM method. Procedia Computer Science 17: 324-331

[5] Wanke P, Azad M A K and Barros C P 2016 Efficiency factors in OECD banks: A ten-year analysis. Expert Systems with Applications 64: 208-227

[6] Zaman M R, Morid S and Delavar M 2016 Evaluating climate adaptation strategies on agricultural production in the Siminehrud catchment and inflow into Lake Urmia, Iran using SWAT within an OECD framework. Agricultural Systems 147: 98-110

[7] Kazan H, Karaman E, Akçalı B Y and Şişmanoğlu E 2015 Assessment of teog examination success: topsis multi-criteria decision-making method practice. Procedia-Social and Behavioral Sciences 195: 915-924

[8] Rashidi K, Shabani A and Saen R F 2015 Using data envelopment analysis for estimating energy saving and undesirable output abatement: a case study in the Organization for Economic Co-Operation and Development OECD countries. Journal of Cleaner Production 105: 241-252 
[9] Mavi R K, Saen R F and Goh M 2018 Joint analysis of ecoefficiency and eco-innovation with common weights in twostage network DEA: A big data approach. Technological Forecasting and Social Change, https://doi.org/10.1016/j. techfore.2018.01.035. In Press

[10] Zhou P, Poh K L and Ang B W 2007 A non-radial DEA approach to measuring environmental performance. European Journal of Operational Research, 1781: 1-9

[11] Kou M, Chen K, Wang S and Shao Y 2016 Measuring efficiencies of multi-period and multi-division systems associated with DEA: An application to OECD countries' national innovation systems. Expert Systems with Applications 46: 494-510

[12] Chow G, Heaver T D and Henriksson L E 1994 Logistics performance: definition and measurement. International Journal of Physical Distribution and Logistics Management 241: $17-28$

[13] Klumpp M, Abidi H, Bioly S, Buchkremer R, Ebener S and Sandhaus G 2017 Logistics Dynamics and Demographic Change. In: Dynamics in Logistics pp. 347-362 Springer, Cham

[14] Kucukaltan B, Irani Z and Aktas E 2016 A decision support model for identification and prioritization of key performance indicators in the logistics industry. Computers in Human Behavior 65: 346-358

[15] Ab Talib M S, Abdul Hamid A B and Chin T A 2016 Can halal certification influence logistics performance? Journal of Islamic Marketing 74: 461-475

[16] Khlie K, Serrou D, and Abouabdellah A 2016 October The impact of Lean-logistics and the information system on the information flow management within the healthcare supply chain. In: Intelligent Systems: Theories and Applications SITA, 2016 11th International Conference, IEEE pp. 1-5

[17] Guner S and Coskun E 2012 Comparison of impacts of economic and social factors on countries' logistics performances: a study with 26 oecd countries. Research in Logistics and Production 2: 330-343

[18] Castrellón-Torres J P, Torres-Acosta J H and Adarme-Jaimes W 2014 Model for the logistics distribution of medicines in the Colombian public health program. Dyna 81187: 257-266

[19] Abidi H, de Leeuw S and Klumpp M 2014 Humanitarian supply chain performance management: a systematic literature review. Supply Chain Management: An International Journal 195/6: 592-608

[20] Biswas T and Samanta S 2016 A strategic decision support system for logistics and supply chain network design. Sādhanā 416: 583-588

[21] Wong D W, Choy K L, Chow H K and Lin C 2014 Assessing a cross-border logistics policy using a performance measurement system framework: the case of Hong Kong and the Pearl River Delta region. International Journal of Systems Science 456: 1306-1320

[22] Aydogan E K 2011 Performance measurement model for Turkish aviation firms using the rough-AHP and TOPSIS methods under fuzzy environment. Expert Systems with Applications 384: 3992-3998

[23] Ozmen M, Aydogan E K, Ates N and Uzal N 2016 Developing a decision-support system for waste management in aluminum production. Environmental Modeling and Assessment 216: 803-817

[24] Ambrosini C and Routhier J L 2004 Objectives, methods and results of surveys carried out in the field of urban freight transport: an international comparison. Transp. Rev. 24 (1): $57-77$

[25] Gergin RE and Baki B 2015 Evaluation by integrated AHP and TOPSIS method of logistics performance in Turkey's regions. Bus. Econ. Res. J. 6 (4): 115-135 (in Turkish).

[26] Yang Y C and Chen S L 2016 Determinants of global logistics hub ports: Comparison of the port development policies of Taiwan, Korea, and Japan. Transport Policy 45: 179-189

[27] Özceylan E, Çetinkaya C, Erbaş M and Kabak M 2016 Logistic performance evaluation of provinces in Turkey: A GIS-based multi-criteria decision analysis. Transportation Research Part A: Policy and Practice, 94: 323-337

[28] Roy V, Mitra S K, Chattopadhyay M and Sahay B S2017 Facilitating the extraction of extended insights on logistics performance from the logistics performance index dataset: A two-stage methodological framework and its application. Research in Transportation Business and Management, https://doi.org/10.1016/j.rtbm.2017.10.001. In Press

[29] Yu M and Hsiao B 2015 Measuring the technology gap and logistics performance of individual countries by using a meta-DEA-AR model. Maritime Policy Manage 43 (1): 98-120

[30] Çakır S 2017 Measuring logistics performance of OECD countries via fuzzy linear regression. Journal of Multi-Criteria Decision Analysis 24(3-4): 177-186

[31] Jiang C and Chen D 2009 Research on urban logistics infrastructure: an empirical study of China. Journal of Service Science and Management 2: 80-91

[32] Gomes L F 1989 Multicriteria ranking of urban transportation system alternatives. Journal of Advanced Transportation 231: 43-52

[33] Tversky A and Kahneman D 1992 Advances in prospect theory: Cumulative representation of uncertainty. Journal of Risk and Uncertainty 54: 297-323

[34] Gomes L F A M 2009 An application of the TODIM method to the multicriteria rental evaluation of residential properties. European Journal of Operational Research 1931: 204-211

[35] Gomes L F A M, Rangel L A D and Maranhão F J C 2009 Multicriteria analysis of natural gas destination in Brazil: An application of the TODIM method. Mathematical and Computer Modelling 501-2: 92-100

[36] Passos A C, Teixeira M G, Garcia K C, Cardoso A M and Gomes L F A M 2014 Using the TODIM-FSE method as a decision-making support methodology for oil spill response. Computers and Operations Research 42: 40-48

[37] Soni, N, Christian R A and Jariwala N 2016 Pollution Potential Ranking of Industries Using Classical TODIM Method. Journal of Environmental Protection 711: 1645

[38] Zhang X and Xu Z 2014 The TODIM analysis approach based on novel measured functions under hesitant fuzzy environment. Knowledge-Based Systems 61: 48-58.s

[39] Mahalanobis P C 1936 On the generalized distance in statistics. National Institute of Science of India, 2: 49-55

[40] Wang Z X and Wang Y Y 2014 Evaluation of the provincial competitiveness of the Chinese high-tech industry using an improved TOPSIS method. Expert Systems with Applications 416:2824-2831

[41] Haughwout A F 2001 Infrastructure and social welfare in metropolitan America. Economic Policy Review 73: 43-54 
[42] Ojala L and Celebi D 2015 February The World Bank's Logistics Performance Index LPI and drivers of logistics performance. In document préparé pour la Table ronde du Forum international des transports sur les stratégies de développement logistique et leurs indicateurs de résultats 9-10 mars 2015, Queretaro, Mexique

[43] Saidi S and Hammami S 2011 May The role of transport and logistics to attract foreign direct investment in the developing countries. In: Logistics (LOGISTIQUA), 2011 4th International Conference on (pp. 484-489). IEEE

[44] Website:https://lpi.worldbank.org/

[45] OECD 2018 "Freight transport" indicator, https://doi.org/10. 1787/708eda32-en accessed on 03 July 2018
[46] OECD 2018 Container transport indicator https://doi.org/10. 1787/26de63f3-en Accessed on 04 July 2018

[47] OECD 2018 Passenger transport indicator https://doi.org/10. 1787/463da4d1-en Accessed on 04 July 2018

[48] Saaty T L 2003 Decision-making with the AHP: Why is the principal eigenvector necessary. European Journal of Operational Research 1451: 85-91

[49] Ozmen M, Kızılkaya Aydogan E and Zaralı F 2015 Logistics center location selection using the new method SMAATODIM. MCDM 2015

[50] Aydogan E K and Ozmen M 2017 The stochastıc vikor method and its use in reverse logistic option selection problem. RAIRO-Operations Research 512: 375-389 